\title{
Systemowa mechanika zmiany - innowacja i postęp w świetle nauki o komunikacji
}

\section{Punkt wyjścia — projektowanie komunikacji}

Kategorie innowacji i postępu w odniesieniu do rezultatu procesu projektowego, czyli do funkcjonujących ofert komunikacyjnych, omówię w niniejszym tekście w kontekście projektowania komunikacji z uwzględnieniem subsystemu projektowania komunikacji - product design. Na wstępie chciałbym zauważyć, że projektowanie komunikacji jako dziedzina nauki i projektowania jest systemowo warunkowana zjawiskami: designu, komunikacji i społeczeństwa.

Projektowanie komunikacji jest procesem, którego wiodącą właściwością jest organizowanie i stabilizowanie życia społecznego w obszarze dostarczania funkcjonalnych rozwiązań problemów projektowych. Projektowanie komunikacji to interdyscyplinarna przestrzeń projektowa, w której powstający i istniejący model świata, jak i o ile zostanie ukształtowany przez człowieka, jest produkowany w ramach komunikacji i przy jej pomocy jest również utrzymywany. W związku z tym design wynika z komunikacji oraz ją powoduje. Ta zaś z uwagi na stabilizowanie własnych struktur tworzy społeczeństwo rozumiane jako system komunikacyjnych powiązań ${ }^{1}$. Tym samym komunikacja będzie centralnym procesem napędzającym się samozwrotnie z wykorzystaniem mechanizmu wytwarzania komunikacji i ofert komunikacyjnych (design), czego wynikiem będzie utrzymanie komunikacji, czyli w rezultacie funkcjonowanie społeczeństwa. Chodzi więc o to, żeby komunikacja wywołała komunikację, ponieważ rezultaty jej oddziaływań będą produkowały struktury społeczne - proces ten można porównać do efektu domina, ale bez założonego wcześniej początku

\footnotetext{
${ }^{1}$ Por. N. Luhmann, Systemy społeczne. Zarys ogólnej teorii, przeł. M. Kaczmarczyk, Kraków 2007.
} 
i końca; to trochę perpetuum mobile w wymiarze niematerialnym, choć przedmiotem komunikacji są też rzeczy materialne.

Samo projektowanie można rozumieć nie jako obiekt postrzegania z uwzględnieniem atrybutu funkcjonalności i określonej estetyki, jak to często jest wskazywane $\mathrm{w}$ literaturze przedmiotu ${ }^{2}$, lecz raczej jako proces, który jest zorientowany na ro wiązywanie problemów i dostarczanie rozwiązań prostych w zastosowaniach. Rozwiązań, które w wyniku procesu projektowego - zinstytucjonalizowanego, czyli podejmowanego $\mathrm{w}$ ramach profesjonalnych komunikacji, czy też niezinstytucjonalizowanego, a więc $\mathrm{w}$ ramach codziennych komunikacji - funkcjonują następnie w ramach komunikacji, a co za tym idzie - stają się komunikacją. Stabilizowanie się i nawiązywalność gwarantuje pojawienie się kolejnych komunikacji - sama komunikacja zapewnia przede wszystkim przewidywalność przewidywań, dzięki czemu dochodzi do stabilizowania struktur społecznych.

„Pozbawiony struktury chaos byłby absolutnie niepewny i tylko ta niepewność byłaby pewna"3 - w tym sensie design, komunikacja i społeczeństwo to zjawiska wykazujące charakter cyrkularny: design rozumiany jako proces zorientowany na rozwiązywanie problemów wymaga powstania tych problemów, a te z uwagi na komunikacyjną konstrukcję systemu społecznego pochodzą wprost ze społeczeństwa, które zostało wyprodukowane przy pomocy komunikacji (zob. rysunek 1). Rozwiązywanie problemów (design) daje zaś podstawę generowania znaczeń na okoliczność oferowanych rozwiązań (oferta komunikacyjna).

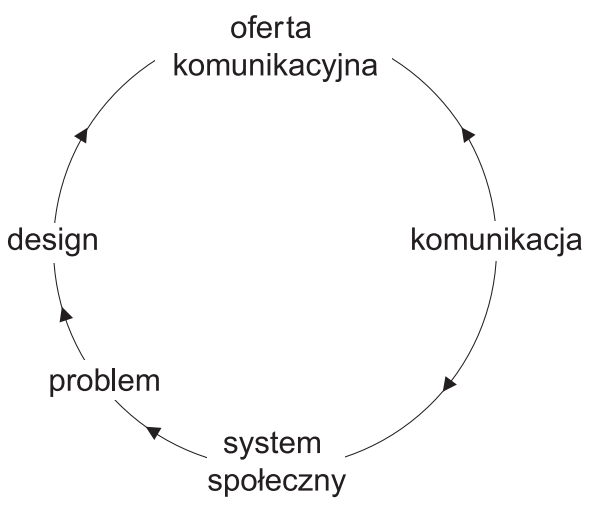

Rysunek 1. Cyrkularny model projektowania komunikacji

Źródło: opracowanie własne.

2 B. Munari, D. Santana, Design e comunicação visual, Lisboa 1982; D.A. Norman, How might people interact with agents, „Communications of the ACM” 37, 1994, nr 7, s. 68-71; D. Sudjic, The Language of Things: Understanding the World of Desirable Objects, New York 2008.

${ }^{3}$ N. Luhmann, op. cit., s. 287. 
Komunikacja w tym kontekście jest rozumiana jako negocjowanie znaczeń, przez co niechcący powstaje społeczeństwo ${ }^{4}$.

Przenosząc tę koncepcję na grunt projektowania komunikacji, nietrudno zauważyć, że w wymiarze zinstytucjonalizowanych komunikacji projektowanie komunikacji nie projektuje komunikacji jako takiej, lecz zapewnia, poprzez dostarczanie ofert komunikacyjnych, konstruowanie znaczeń, o których można już w wymiarze społecznym komunikować. Konstrukcja znaczeń jest w tym wypadku samozwrotnym procesem poznawczym, przypisanym obserwatorowi $\mathrm{w}$ ramach procesu poznania. „Świat, który przeżywamy, jest taki i musi być taki, jaki jest, ponieważ my go takim zrobiliśmy"5 - czyli projektowanie komunikacji zapewnia możliwość podjęcia komunikacji w ramach dostępnych struktur komunikacyjnych, co wprost przekłada się na Luhmannowską koncepcję, że to nie ludzie komunikują, a komunikacja ${ }^{6}$.

Stabilizowanie i organizowanie życia społecznego przy pomocy projektowania komunikacji odbywa się na gruncie wyspecjalizowanych subsystemów dyscyplin projektowych, które choć wykazują współzależną relację między tymi subsystemami, z punktu widzenia funkcji i formy pozostają obszarami autonomicznymi z perspektywy procesu projektowego. Szeroko o subsystemach dyscyplin projektowych pisze m.in. Michael Fleischer w książce Communication design, czyli projektowanie komunikacji, w której konstatuje, że

mamy do czynienia z wymiarem wynikającym z działań i w działaniach się manifestującym. W tym wymiarze proces communication design składa się, $\mathrm{w}$ moim rozumieniu, $\mathrm{z}$ pięciu uzupełniających się podsystemów: z corporate identity, z designu informacji i grafiki (typografia, layout, prezentacje, systemy orientacyjne), z designu powierzchni (web design), z designu opakowań oraz z designu produktów ${ }^{7}$.

Nie wdając się już w krytyczne, rzecz jasna, dywagacje na temat zaproponowanego przez Fleischera podziału systemu projektowania komunikacji, za istotne uznaję wskazanie, że nie są to systemy zamknięte. O ile można jednoznacznie wykazać autonomiczny charakter subsystemów projektowania komunikacji z punktu widzenia funkcji, a nierzadko i formy, trudno jest z perspektywy gotowych ofert komunikacyjnych nie uwzględnić intersystemowego charakteru owych subsystemów. Chodzi więc o to, że wymienione i omówione przez Fleischera subsystemy systemu projektowania komunikacji są od siebie zależne i wzajemnie się przenikają. Przykładem niech będzie subsystem designu produktu, który jest zorientowany na dostarczanie rozwiązań w wymiarze wzorniczym i produktowym. Według Fleischera design produktu to bowiem

${ }^{4}$ Por. M. Fleischer, Communication design, czyli projektowanie komunikacji, Łódź 2010.

${ }^{5}$ Zob. E. von Glasersfeld, The Construction of Knowledge. Contributions to Conceptual Semantics, Salinas 1987.

${ }^{6}$ Por. N. Luhmann, Soziale Systeme. Grundriss einer allgemeinen Theorie, Frankfurt am Main 1984.

${ }^{7}$ M. Fleischer, op. cit., s. 200. 
usługa zajmująca się kształtowaniem wszystkich otaczających nas produktów przemysłowych, nie tylko z punktu widzenia ich wyglądu oczywiście, lecz przede wszystkim wykreowania ich jako takich, ukształtowania ich funkcji lub wygenerowania nowych funkcji, a następnie ich urynkowienia i przygotowania do użycia, oraz zaprojektowanie ich likwidacji, czyli recyclingu w sposób ekologicznie akceptowalny ${ }^{8}$.

Design produktu będzie dotyczył w głównej mierze wykorzystania designu do transparentnego operowania funkcją produktu — chodzi zatem o to, żeby w wymiarze projektowym umieć odpowiedzieć na pytanie (i wdrożyć tę odpowiedź w życie), w jaki sposób design tłumaczy powierzone produktowi funkcje, by móc bezproblemowo używać posiadanego produktu. Ale produkt to nie tylko wymiar przemysłowo-funkcjonalny, to również wymiar wizerunkowy, a nierzadko i informacyjny, $\mathrm{w}$ ramach którego dochodzi do uwzględnienia $\mathrm{w}$ procesie projektowym subsystemów: corporate identity i designu informacji. Pierwszy subsystem odpowiada za wyróżnienie produktu na tle innych tego typu produktów w zakresie tożsamości organizacyjnej - przez wygląd i charakter produkt daje podstawę tworzenia (się) corporate image samego produktu i stojącej za nim organizacji. Drugi subsystem odpowiada za semantyzowanie obszaru informacyjnego produktu (np. jak to działa?) i orientację w przestrzeni samego produktu (np. jak mogę tego użyć?). Reasumując, można stwierdzić, że projektowanie komunikacji jest systemem, w ramach którego wyróżnia się otwarte subsystemy dyscyplin projektowych, które z uwagi na kompleksowość ofert komunikacyjnych przenikają się i uzupełniają w odniesieniu do funkcji właściwej danemu subsystemowi, a także $\mathrm{w}$ ramach procesu projektowego tworzą hierarchiczne struktury powiązań subsystemów z jednym subsystemem wiodącym i kolejnymi subsystemami pośredniczącymi.

\section{Innowacja i postęp w kontekście projektowania komunikacji}

Zarówno kategoria innowacji, jak i kategoria postępu są szeroko opisywane w literaturze przedmiotu ze szczególnym uwzględnieniem nauk ekonomicznych ${ }^{9}$ i nierzadko tematyzowane w kontekście designu produktu. Zwłaszcza kategoria innowacji jest tutaj wprost łączona $\mathrm{z}$ rozwojem technologicznym, któremu przypisuje się jednoznaczny związek z procesem projektowym dla wymiaru przemysłowego i wzorniczego. Wiodące pytania projektowe dla designu produktu odnoszą się, z jednej strony, do funkcji produktu, a $\mathrm{z}$ drugiej - do stojącej za nim technologii. Taka sytuacja

${ }^{8}$ Ibidem, 203.

9 Por. np. P.F. Drucker, The Practice of Management, London 1968; M. Panek-Owsiańska, Innowacje społeczne, [w:] Wspólna odpowiedzialność. Rola innowacji, red. N. Ćwik, Warszawa 2013, s. 42-45; K. Rózicka, M. Cieślak, Zrównoważone innowacje - studia przypadków firm polskich i zagranicznych, [w:] Wspólna odpowiedzialność... 
— czyli bezpośrednia relacja technologii i wzornictwa - jak sądzę, implikuje tematyzowanie komunikacji właśnie w obszarze innowacji i postępu w designie w ogóle.

Co w tym interesujące, to właśnie przełożenie komunikacji na faktyczną zmianę w kontekście rozwiązywania problemów projektowych. Czy jednak faktycznie można wykazać zależność między kategoriami „innowacji” i „postępu”?

Literatura przedmiotu wskazuje na kategorię innowacji jako działania związane z wytworzeniem nowych lub ulepszonych rezultatów tych działań. Punkt ciężkości opisu w tym kontekście jest postawiony na kategorię rozwoju w dowolnie interpretowanym zakresie. Odnosząc się do opracowanego przez Josepha A. Schumpetera pojęcia innowacji we współczesnej formie, musimy stwierdzić, że innowacja „zachodzi, jeśli nowe kombinacje występują w sposób nieciągły, wówczas powstaje zjawisko charakterystyczne dla rozwoju" ${ }^{10}$. Rozwojem w ujęciu Schumpetera jest więc przeprowadzenie nowych kombinacji ${ }^{11}$.

Inaczej pojęcie to widzi Anna Oleniczuk-Merta, która w przeciwieństwie do Schumpetera wskazuje na ewolucyjny charakter zjawiska zarówno w kontekście gospodarczym, jak i społecznym. Autorka artykułu Innowacje społeczne zaznacza jednak, że pojęcie innowacji w literaturze przedmiotu, szczególnie w literaturze ekonomicznej,

nigdy nie było i nie jest jednolite. Występuje duże zróżnicowanie poglądów na temat innowacji, a także aspektów, według których zmiany innowacyjne są analizowane i oceniane. Podstawowe z nich odnoszą się do: (1) charakteru zmian, (2) zakresu zmian, (3) czasu wprowadzania zmian, (4) efektów zmian ${ }^{12}$.

O tym, że kategoria innowacji jest różnie operacjonalizowana w literaturze przedmiotu, świadczy również koncepcja Sumnera Mayersa i Donalda G. Marquisa, którzy rozumieją innowację jako proces „przebiegający od koncepcji, nowej idei do rozwiązania problemu, a następnie do bieżącego wykorzystania ekonomicznych i społecznych zalet nowego"13. Stwierdzenie to odnosi się jednak raczej do struktury procesu projektowego w ramach designu, rozumianego jako rozwiązywanie problemów i dostarczanie rozwiązań prostych w użyciu ${ }^{14}$.

Wieloznaczność pojęcia innowacji oraz sytuowanie go poza kategorią nauk ekonomicznych, szczególnie w kontekście procesów projektowych i procesów wytwórczych, dało podstawę do próby nakreślenia systemu zależności pojęć w relacji „innowacja-postęp". Właśnie przez próbę zestawienia pojęcia innowacji z postępem widzę możliwość ich systemowego opisu bez trudności związanych $\mathrm{z}$ wewnątrzsystemowym rozstrzyganiem zakresu obowiązywania. W związku z tym, że kategoria postępu, uwzględniwszy teorię postępu, jest paradygmatycznie bliska kategorii innowacji — odnosi się w głównej mierze do rozwoju i udoskonalenia czegoś; przejścia z jedne-

10 J.A. Schumpeter, Theorie der wirtschaftlichen Entwicklung, Leipzig 1960, s. 104.

${ }^{11}$ S. Marciniak, Innowacyjność i konkurencyjność gospodarki, Warszawa 2010.

12 A. Olejniczuk-Merta, Innowacje społeczne, „Konsumpcja i Rozwój” 2013, nr 1, s. 21-34.

${ }^{13}$ Ibidem, s. 21.

14 Por. M. Wszołek, Reklama - operacjonalizacja pojęcia, Kraków 2015. 
go etapu do drugiego - wydaje się odpowiednia dla nakreślenia systemu zależności tych dwóch pojęć. Pojęcie innowacji i postępu będę rozumiał jako mechanizmy sterujące rozwojem na dwóch różnych płaszczyznach, na co wskazuje również Harald Welzer, pisząc:

w odróżnieniu od „postępu” „innowacja” nie posiada treści, nie służy do czegoś, lecz jej jakość zawarta jest jedynie w tym, że wobec czegoś innego jest „nowa”"15.

W wypadku innowacji możemy mówić o zmianie wystąpienia w ramach danej kategorii, zaś w przypadku postępu - o zmianie wystąpienia całej kategorii. Kategoria w tym kontekście będzie wartością właściwą sektorowi gospodarki, a ze względu na wysoki poziom kompleksowości - bliżej nieokreślona. Ta subtelna różnica jest tutaj, jak sądzę, bardzo istotna - odnosi się bowiem do perspektywy zewnątrzsystemowej, która jest właściwa dla kategorii postępu, oraz do perspektywy wewnątrzsystemowej, która odpowiadać będzie kategorii innowacji. Zakładając, że mamy do czynienia $\mathrm{z}$ kategorią $\mathrm{X}, \mathrm{w}$ ramach której występują różne produkty, możemy powiedzieć, że innowacja będzie dotyczyła rozwoju/zmiany produktu w ramach kategorii $\mathrm{X}$ bez wpływu na wystąpienie kategorii Y. Postęp w takim wypadku będzie wiązał się ze zmianą występowania kategorii X i prowadzi do wyłonienia się kategorii $\mathrm{Y}$. W tym miejscu należy zaznaczyć, że w wypadku wyłonienia się kategorii Y kategoria X może nadal funkcjonować, co postaram się wykazać w dalszej części artykułu.

Relację innowacji i postępu można odnieść do relacji dywersyfikacji i dyferencjacji zaproponowanej przez Michaela Fleichera w odniesieniu do Jakobsonowskiej koncepcji osi analizy języka i generowania wypowiedzi za pomocą języka ${ }^{16}$. Fleischer wykorzystał tę koncepcję do wyjaśnienia sposobów reprodukcji systemów w kontekście mechanizmu dywersyfikacji i dyferencjacji.

„Dywersyfikacja” niech zdefiniowana będzie jako powielanie elementów systemu wraz z jego strukturą, rozumianą tu jako producent tego systemu; dywersyfikacja zatem odbywa się w ramach struktury. „Dyferencjacja” natomiast niech zdefiniowana będzie jako transportowanie elementów systemu i tworzenie w tym celu własnych struktur tych elementów; dyferencjacja zatem powstaje ze struktur i odbywa się między strukturami ${ }^{17}$.

Wynika stąd, że to mechanizmy dywersyfikacji i dyferencjacji są odpowiedzialne za systemową produkcję obiektów komunikacji czy też sposobności komunikacyjnych. W przypadku dywersyfikacji dochodzi do produkcji elementów systemu, które są od siebie różne, ale są produktami tego właśnie systemu - tym samym system

${ }^{15}$ H. Welzer, Die smarte Diktatur. Der Angriff auf unsere Freiheit, Frankfurt am Main 2016.

${ }^{16}$ Por. R. Jakobson, Linguistics and poetics, [w:] Style in Language, red. T.A. Sebeok, Cambridge 1960, s. 350-377; w języku polskim: R. Jakobson, Co to jest poezja?, [w:] Praska szkoła strukturalna w latach 1926-1948. Wybór materiałów, red. M.R. Mayenowa, przeł. W. Górny, T. Brajerski, Warszawa 1966, s. 112-129.

${ }^{17}$ M. Fleischer, Dwa rodzaje reprodukcji systemów - dywersyfikacja i dyferencjacja, [w:] Komunikatywizm w Polsce. Wybrane zagadnienia z teorii i praktyki, red. G. Habrajska, Łódź 2011, s. 77. 
jako producent dąży do utrzymania siebie w kontekście powielenia struktur i elementów systemu. I właśnie kategoria dywersyfikacji odpowiada kategorii innowacji - innowacja jako system i producent dąży bowiem do utrzymania siebie. Dyferencjacja natomiast odbywa się bez perpetuowania elementów systemu i samego systemu, przez co w czasie produkuje nowe systemy, które zawierają również nowe elementy ${ }^{18}$. W tym kontekście dochodzi zatem do wystąpienia zmiany kategorii $\mathrm{X}$ $\rightarrow$ Y. Oznacza to, że z punktu widzenia postępu kategoria X może egzystować obok kategorii Y i odwrotnie, czyli kategorie te nie będą się zwalczać, jak ma to miejsce w wypadku innowacji (dywersyfikacji). Innowacja przez produkowanie coraz to nowszych rozwiązań korzysta $\mathrm{z}$ konceptu czasu i idącego za tym dualistycznego wymiaru: aktualizacja-dezaktualizacja. Coś, co jest „nowe”, jest aktualne, zaś coś, co przed pojawieniem się „nowego", było "nowe”, staje się nieaktualne, ponieważ nie może koegzystować z obecnym „nowym”. Problem w tym, że aktualne „nowe” za chwilę przestanie takie być.

Należy w tym miejscu wyróżnić jeszcze kwestię manifestacji systemu i samego systemu, co w przypadku innowacji i postępu będzie analogiczne do dywersyfikacji i dyferencjacji. W wypadku innowacji można mówić o różnych manifestacjach systemu, które jednak sprowadzają się do systemu nadrzędnego - innymi słowy, system nadrzędny będzie produkował swoje różne oblicza. Postęp natomiast odbywa się przez reprodukcję systemów, przez co powstaje konkurencyjność systemów bez jednoosiowych hierarchii, co jest właściwością innowacji. Postęp, podobnie jak dyferencjacja, tworzy wariabilność i widoczną konkurencyjność semantyk, modeli, obrazów świata i systemów - jest tym samym mechanizmem tworzenia tego, co uznawane jest w komunikacjach za nowe, inne, niespotykane, czyli m.in. za kreatywne. „O ile zatem innowacja bazuje na zastosowaniu schematu relacyjnego "nowe«, o tyle postęp bazuje na zupełnie innym schemacie, na - »inne «"19 — i właśnie w tym miejscu widzę potrzebę odniesienia kategorii innowacji i postępu do pojęcia kreatywności, które rozumiem jako „sterowaną irytację komunikacyjną w celu osiągnięcia uwagi; to zagospodarowanie uwagi przy pomocy komunikacyjnej irytacji samej komunikacji”20. Kreatywność będzie zatem konstruktem stabilizującym system relacji innowacja-postęp. Odnosząc to do kategorii dyferencjacji i dywersyfikacji, można więc stwierdzić, że

[w] tym sensie dywersyfikacja to unikanie kreatywności na korzyść powielania rozwiązań już istniejących, a dyferencjacja to unikanie rozwiązań zastanych, obecnych już na rynku komunikacji, na korzyść tworzenia czegoś nowego, dotychczas nieistniejącego ${ }^{21}$.

\footnotetext{
18 Por. ibidem.

19 M. Fleischer, Konstrukcja rzeczywistości 3, Kraków 2017, s. 14.

${ }^{20}$ M. Fleischer, Dwa rodzaje reprodukcji systemów..., s. 77.

${ }^{21}$ Ibidem.
} 
Oznacza to, że w związku z wewnątrzsystemową organizacją kategorii innowacji innowacja będzie unikaniem kreatywności. Co innego w wypadku kategorii postępu, który by móc zaistnieć, wymaga rozwiązań nowych, do tej pory nieistniejących.

W związku z tym, że kreatywność będzie przypisana bezpośrednio kategorii postępu, należy w ramach omawianego systemu zależności wprowadzić jeszcze jedno pojęcie, które będzie odpowiedzialne za konstruowanie się manifestacji zarówno w obszarze innowacji, jak i postępu. Do pełnego opisu brakuje zatem tylko pojęcia procesu projektowego, gdyż zakładam, że każda postrzegalna oferta komunikacyjna (niezależnie od tego, w jakim kontekście jest sytuowana: innowacja-postęp / dywersyfikacja-dyferencjacja) jest rezultatem procesu projektowego. W związku z tym, że pojęcie designu zostało tu wprowadzone w kontekście procesu projektowania komunikacji i scharakteryzowane jako proces zorientowany na rozwiązywanie problemów projektowych, wskazuję $\mathrm{w}$ tym miejscu jedynie na możliwe rozumienie tej kategorii jako generalnego producenta systemu, dla którego innowacja i postęp są produktami o różnych właściwościach systemowych. Tym samym omawiana w tej części artykułu zależność składa się z następujących elementów: (1) design - producent systemu, (2) kreatywność - konstrukt stabilizujący system, (3) innowacja i postęp - produkty systemu (zob. rysunek 2).

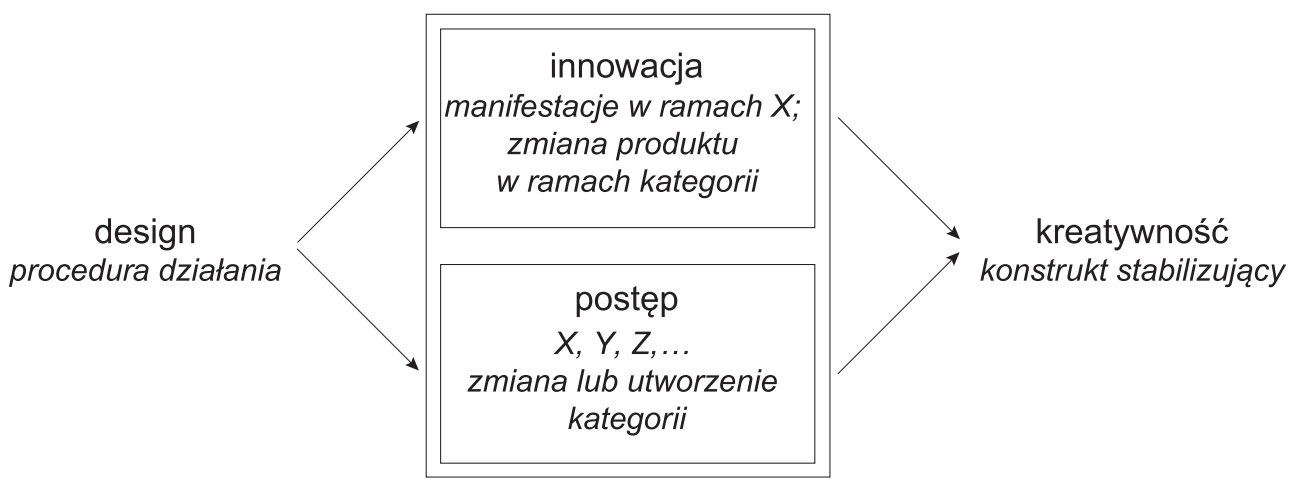

Rysunek 2. Zależność innowacji i postępu w kontekście procedury działania

Źródło: opracowanie własne.

Innowacja i postęp - analiza zjawiska w obszarze telefonii komórkowej

W nawiązaniu do przeprowadzonej tu operacjonalizacji kategorii innowacji i postępu w odniesieniu do projektowania komunikacji prześledzę $-\mathrm{w}$ charakterze przykładu - rozwój nowych technologii w obszarze telefonii komórkowej. Sektor 
ten można w kontekście innowacji, czyli wspomnianego rozwoju produktu w ramach danej kategorii, opisać jako, z jednej strony, zmniejszanie rozmiarów samego telefonu komórkowego - początkowa faza rozwoju, w którym lepsze telefony to te, które są mniejsze od swoich poprzedników, a z drugiej strony, również jako zwiększanie samego telefonu komórkowego - faza rozwoju, w którym większy telefon to produkt lepszy 22 .

W odniesieniu do postawionej w niniejszym artykule tezy dotyczącej kategorii postępu nie zauważam, żeby w kategoriach funkcjonalnych model NOKIA 3210 znacząco różnił się od najnowszego modelu iPhone’a. Zarówno telefon komórkowy marki NOKIA, jak i telefon komórkowy marki iPhone spełniają te same funkcje z perspektywy końcowego użytkownika (end user), czyli: funkcja informacyjna, funkcja rozrywki i funkcja komunikacyjna (dalej: empiryczna egzemplifikacja tej tezy). Oba telefony, choć technologicznie znajdują się w dwóch wymiarach technologicznego zaawansowania, są z perspektywy zewnątrzsystemowej do siebie bardzo podobne. Tym samym można zauważyć, że w ramach sektora telefonii komórkowej nie doszło do żadnego postępu, a w kategoriach innowacji to, co kiedyś było przejawem dezaktualizacji, jest obecnie aktualizacją. Rozwój telefonii komórkowej nie doprowadził w kontekście postępu do żadnej zmiany samej kategorii lub wyłonienia się alternatywnej kategorii. Telefon komórkowy w wymiarze funkcjonalnym zmienia się jedynie na poziomie wzorniczym (wielkość, kształt, forma) oraz technologicznym (moc obliczeniowa). Interesujące jest, że z perspektywy funkcji telefon komórkowy w ciągu ostatnich lat nie zmienił się. Nie można oczywiście zaprzeczyć zmianie manifestacji systemu w omawianym obszarze (innowacja), ale stanowczo można zanegować zmianę samego systemu (postęp).

O ile zatem innowacja bazuje na zastosowaniu schematu relacyjnego „nowe”, o tyle postęp bazuje na zupełnie innym schemacie, na - „inne”. Mamy zatem, na przykład, rower, a tu pojawia się (czyli oferowany jest) nowy rower, który od poprzedniego różni się tym jedynie, że jest nowy; patrz plakat firmy RTV Euro AGD ${ }^{23}$ — „bierz nowe, wyrzuć stare” — jest on nadal rowerem, tyle że posiada coś, czego poprzedni nie miał (niechby nawet tylko niższą cenę), i dlatego jest nowy. Ale, weźmy inną sytuację, mamy rower, a tu pojawia się samochód; niby podobne coś, ale jednak inne, gdyż otwiera nowe możliwości (czy sensowne, to już inna kwestia); u podłoża konstrukcji samochodu leży kategoria inności ${ }^{24}$.

Akceleratorami procesu innowacji mogą być tutaj dyferencje rynkowe, czyli powtarzalne tematy komunikacji zorientowane na produkowanie się świata przeżyć produktu, marki.

Dyferencje rynkowe to mechanizm generujący i utrzymujący produkowanie się świata przeżyć marki, produktu czy całego sektora gospodarki. Rezultatem tego mechanizmu będą kategorie poznawczo-

22 Zob. https://funalive.com/articles/the-evolution-of-cell-phones_W3M.html (dostęp: 3.03.2017).

${ }^{23} \mathrm{http} / /$ www.galeria-rzeszow.pl/db/news_photos/a39c02e1b2.png (dostęp: 10.06.2017).

${ }^{24}$ M. Fleischer, Konstrukcja rzeczywistości 3, s. 173. 
-interpretacyjne, za których pośrednictwem powstają dyferencje produktów w obszarze możliwych ofert komunikacyjnych ${ }^{25}$.

W wypadku omawianej telefonii komórkowej za takie dyferencje rynkowe można uznać wzornictwo (początkowa faza: minimalizowanie telefonu komórkowego, końcowa faza: maksymalizowanie wyświetlacza i samego telefonu), moc obliczeniową (ciągły wzrost), wyłonienie się alternatywnych systemów operacyjnych, pojawienie się aparatu fotograficznego i aplikacji, upowszechnienie dostępu do Internetu oraz zasadnicze upowszechnienie przenośnego charakteru urządzenia do komunikacji. Co interesujące, telefony komórkowe i smartphony służą z punktu widzenia posiadanych (technologicznie) funkcjonalności tej samej krótkiej liście funkcji: rozrywce, komunikacji, informacji i przechowywaniu (np. informacji). Może to wskazywać, że funkcja produktu jest nadana w komunikacji, czyli jest konstytuowana przez komunikację i utrzymywana w ruchu - nie wynika z samego produktu. Podobnie rzecz się ma w przypadku innowacji, która sama w sobie nie daje nowych możliwości, a jedynie staje się przedmiotem dyskusji o nich. Pierwsze telefony komórkowe są takimi samymi telefonami komórkowymi - w sensie funkcji - co ich współczesne odpowiedniki w postaci smartphonów. W podobnym tonie konstatuje dyrektor muzeum designu w Londynie:

Pierwszy laptop, lustrzanka czy telefon komórkowy potrzebowały projektanta, który zdefiniowałby, czym ma być laptop, aparat czy komórka. Wszystko, co było później, to wariacja na ten sam temat ${ }^{26}$.

\section{The systemic mechanism of change - innovation and progress in the light of communication science}

Summary

In the article I discuss the concept of innovation and progress with regard to the results of the design process within the framework of the communication design system. I understand the concept of innovation and progress as mechanisms controlling development on two different levels. In the case of innovation we can speak of a change within a given category, while in the case of progress - a change of the entire category. The concept will correspond to a given sector of the economy.

${ }^{25}$ Por. M. Wszołek, Reklama - perspektywa empiryczna, Kraków 2016, s. 111.

${ }^{26}$ D. Sudjic, The Language of Things: Understanding the World of Desirable Objects, New York 2009, s. 58. 